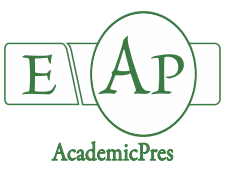

Popa DC et al. (2021)

Notulae Botanicae Horti Agrobotanici Cluj-Napoca

Volume 49, Issue 2, Article number 12340

DOI: $10.15835 /$ nbha 49212340

Research Article

\title{
Nitrate content of spring leafy vegetables from different outlets
}

\section{Dana C. POPA ${ }^{1}$, Răzvan A. POPA ${ }^{2 *}$, Elena N. POGURSCHI ${ }^{3}$, Minodora $^{2}$ TUDORACHE ${ }^{1}$, Cătălin R. VINNTU ${ }^{4}$, Monica P. MARIN ${ }^{3}$, Livia VIDU²}

\author{
${ }^{1}$ University of Agricultural Sciences and Veterinary Medicine of Bucharest, Faculty of Animal Productions Engineering and \\ Management, Ecology and Environment Protection Department, 59 Mărăști, 011464 Bucharest, Romania; \\ danasandulescu@yahoo.com;minodora.tudorache@usamv.ro \\ ${ }^{2}$ University of Agricultural Sciences and Veterinary Medicine of Bucharest, Faculty of Animal Productions Engineering and \\ Management, Experimental Technique and Research Department, 59 Mărăști, 011464 Bucharest, Romania; \\ poparasvan@yahoo.co.uk (*correspondingauthor);liviavidu@gmail.com \\ ${ }^{3}$ University of Agricultural Sciences and Veterinary Medicine of Bucharest, Faculty of Animal Productions Engineering and \\ Management, Nutrition Department 59, Mărăști, 011464 Bucharest, Romania; elena.pogurschi@usamv.ro; \\ marin_monica_zoo@yahoo.com \\ ${ }^{4}$ University of Agricultural Sciences and Veterinary Medicine of Bucharest, Faculty of Management and Rural Development, 59 \\ Mărăsti,011464 Bucharest, Romania; catalin.vintu@managusamv.ro
}

\begin{abstract}
The issue of nitrate contamination has become increasingly acute, with the awareness of their toxicity on the human body and the identification of increasing sources of contamination. Human intervention in the natural nitrogen cycle has serious repercussions that are manifested by its accumulation at one or more levels. The use of fertilizers in agriculture is crucial to ensure food security, but their unreasonable use causes accumulations of nitrogen in the form of nitrate ions in plants, and from here they reach human intake, over a certain amount becoming harmful. The aim of this paper is to quantify the amount of nitrates present in certain vegetables intensively consumed during spring, sources of food which if does not conform with the current recommendations of EFSA and EU, can become major factors of risk to public health. The studied material consists of 5 types of vegetables products intensively consumed in spring: lettuce (Lactuca sativa), curly lettuce (or Lollo - Lactuca sativa var Crispa), Iceberg lettuce (Lactuca sativa lime Iceberg), spinach (Spinacia oleracea) and wild garlic (Allium ursinum). The samples were collected from different commercial locations (outlets): hypermarkets $(\mathrm{H})$, open markets $(\mathrm{OM})$, street trade $(\mathrm{ST})$ and house gate trade (HGT). The highest nitrate concentrations were found in lettuce in ST $\left(4306 \mathrm{mg} \mathrm{kg}^{-1}\right)$ and HGT $\left(4175.5 \mathrm{mg} \mathrm{kg}^{-1}\right)$, in Lollo salad in ST ( $\left.4306.5 \mathrm{mg} \mathrm{kg}^{-1}\right)$ and HGT $\left(4602.75 \mathrm{mg} \mathrm{kg}^{-1}\right)$ and spinach in OM $\left(3469.25 \mathrm{mg} \mathrm{kg}^{-1}\right)$. The study findings suggest that ST and HGT are commercial points that may constitute a danger to public health, the ADI value exceedingly even by $107.21 \%$ in the case of Lollo salad purchased from HGT. The issue calls for more drastic controls by the authorities.
\end{abstract}

Keywords: leafy vegetables; nitrate; outlets; public health; risk factors

Received: 08 Apr 2021. Received in revised form: 25 Apr 2021. Accepted: 12 May 2021. Published online: 25 May 2021.

From Volume 49, Issue 1, 2021, Notulae Botanicae Horti Agrobotanici Cluj-Napoca journal uses article numbers in place of the traditional method of continuous pagination through the volume. The journal will continue to appear quarterly, as before, with four annual numbers. 


\section{Introduction}

Nitrate and nitrite contamination is a current and serious problem. Exposure to these compounds is through food, water, air and soil.

The use of nitrogen-based fertilizers in agriculture has been a great step forward for mankind, making a major contribution to ensuring food security by increasing food production per unit grown. The logic of their application on the soil consists in the reaction of ammonia (from fertilizers) with water from the soil, its transformation into ammonium ion $\left(\mathrm{NH}_{4}^{-}\right)$and adsorption by soil particles. Under the action of bacteria, ammonium is broken down into nitrate, thus available to plants. In case of too much fertilizer administered, more than necessary, nitrates will accumulate in excess in the plants, and some will end up in groundwater or surface water.

Being a natural component of plants, nitrate is considered the most important factor influencing the quality of plant production (Tamme et al., 2010). Regarding the nutritional requirements of the plant, nitrogen plays an essential role, but the application of high concentrations of nitrogen not only leads to environmental contamination, but also to its accumulation in the leaves of vegetable crops, reducing their quality. Ammonium and nitrate ions are the most common sources of nitrogen that influence the growth and chemical composition of plants (Abu-Rayyan et al., 2004; Wang and Li, 2004; Zhang et al., 2007). The effect of these two forms of nitrogen, with an impact on plant growth, depends not only on the cultivated species, but also on the concentrations and relationships between them (Marschner, 2011). Usually, the form in which nitrogen is administered influences the absorption ratio of anions and cations, with consequences on dry matter production and root absorption (Mengel et al., 1994). The quantity and quality of fertilizers applied are key factors that determine the growth, production and quality of leafy vegetables.

There are currently several species of plants of economic interest whose production is not affected if ammonium is the only source of nitrogen (Santamaria and Elia, 1997), but in most cases the plants may show different symptoms of ammonium poisoning (Findenegg, 1987; Guo et al., 2002), indicating that normal plant development requires nitrate as a source of nitrogen (Smiciklas and Belou, 1992; Rideout et al., 1994).

A number of studies show that leafy vegetable nitrogen fertilization, both in terms of administration and concentration, directly influences the production per unit area, nitrate accumulation and ionic composition (Santamaria and Lia, 1997; Simone et al., 2001; Fageria, 2001; Kotsiras et al., 2002; Kopsell et al., 2004; Gorenjac and Cencic, 2013).

Deliberate addition of nitrates and nitrites to food is a well-known fact, they have mainly two major roles in meat products: on the one hand their preservative, preventing the development of the bacterium Clostridium botulinum, extremely toxic to humans, lethal in countless cases, and on the other hand it prints a color acceptable for the market especially sausages (van Duijvenbooden et al., 1989).

Also, vegetables included in the human diet are major sources of nitrates and nitrites, they can reach values of over $85 \%$ of the total intake of such substances in the human diet (Gangoli et al., 1994). The nitrate content thus becomes an important indicator of the quality of plant products (Santamaria, 2006).

A number of vegetables, currently included in the human diet, particularly for our country, especially in certain periods of the year that correspond to periods with food peculiarities for religious reasons, contain large amounts of nitrates. Thus, lettuce, spinach, beets, fennel, cabbage, parsley, carrots, celery, potatoes, cucumbers, leeks, radishes contain large amounts of nitrates (Pennington, 1998), but small amounts of nitrites (Iark Working group on the Evaluation of Carcinogenic Risk to Humans, 2010). In recent years, public health security requirements have led to diversification of production systems in most countries (Emongor et al., 2004; Assimakopoulou, 2006).

Nitrate is the most stable oxidized form of nitrogen, and can be reduced to nitrite by microbial action. In the human body, the presence of nitrates and nitrites increases the probability of occurrence of chemical compounds with major toxicological effect. 
Nitrate is absorbed in the upper segment of the small intestine, the distribution in the body is fast, and the bioavailability is almost $100 \%$, due to the fact that nitrates diffuse into the extracellular compartment. The concentration of nitrates in plasma varies between 30-60 $\mathrm{mol} \mathrm{l}^{-1}$ and can reach $200 \mu \mathrm{mol} \mathrm{l}^{-1}$ in case of an intake of contaminants. The specific metabolism of nitrates has the particularity of the entero-salivary cycle, where approximately $20 \%$ of the amount of ingested nitrates is converted into nitrites by the action of nitrate reductase present in the oral microflora. Oral reduction of nitrates to nitrites is the main source for humans, 70-80\% of nitrate exposure (Iacob et al., 2012). In the acidic environment of the stomach, nitrites are converted to nitric acid and other nitrous compounds (McKight et al., 1997). They can react with amines and form nitrosamines, highly carcinogenic substances (Mensinga et al., 2003).

Ingestion of a large amount of nitrates poses a major risk to human health, ingestion causing irritation of the intestinal mucosa, or inhibiting the transport of oxygen to tissues (Lahl, 1983), they contribute to the development of "blue baby syndrome" or methemoglobinemia in infants (Skipton et al., 1998), as well as nonHodgkin's lymphoma in children (Hudak, 2000). A study conducted in Italy during 2001 revealed that there is a major risk of gastric cancer in the human population due to a high amount of nitrites and small amounts of antioxidants. Also, a positive correlation was established between the incidence of gastric cancer and high levels of nitrates in the intake (Palli et al., 2001). Similar studies have been performed on other oncological pathologies, establishing clear links between nitrate consumption and cancer of the stomach, bladder, prostate, colon (Morales-Suarez-Varela et al., 1995). Gatseva et al. (2007) highlight the intake of nitrates as a risk factor in thyroid dysfunction (Gatseva et al., 2007).

Along with the high consumption of these vegetables in the spring, either for physiological needs or for religious reasons, the importance of the sanitation of these plant species increases significantly if we consider the role of their medicinal plants, whether scientifically proven or only for reasons which belong to tradition.

Lettuce (Lactuca sativa) is one of the most valuable vegetables for human consumption, with a high nutritional importance given the content of ascorbic acid, vitamin $\mathrm{A}$, vitamin $\mathrm{K}$, folate, but also as a medicinal plant whose role lies in its high content of flavonoids, tocopherols and carotenoids, with a strong antioxidant role. The special advantage of this vegetable species is given by its worldwide use and the fact that, almost everywhere in the world, it is consumed mainly raw, thus preserving its nutritional value (Still, 2007).

Spinach (Spinacia oleracea) is a also worldwide plant due to its nutritional and medicinal qualities. Spinach is a major source of fiber, vitamins A, E, K, ascorbic acid, vitamins B2 and B6, iron, copper, phosphorus, zinc, calcium, potassium, selenium, folate, folic acid, niacin, carotenoids, flavonoids (Gaikwad et al., 2010; Verma, 2018). Consequently, spinach is an important medicinal plant, used for its role as emollient, antipyretic, diuretic, laxative, anthelmintic, anti-inflammatory, elimination of kidney stones, gallstones, treatment of dermatological diseases etc. (Metha and Belemkar, 2014; Verma, 2018).

The Alliaceae family, which includes wild garlic (Allium ursinum) but also common garlic (Allium sativum), contains plants with an important medicinal role, due to the high content of polyphenols (Chen et al., 2013; Oszmianski et al., 2013), with an important antioxidant role, and medicinal extracts from these plants could even replace the chemical compounds used in various therapies (Trifunschi et al., 2017).

Legislation concerning the maximum nitrate content in leafy vegetables (lettuce and spinach) was introduced by the Commission Regulation (EU) no 1258/2011, according to time of harvest, type of production (in the open air, under cover), or type of conservation (in case of spinach).

In 2008, European Food Safety Authority (EFSA) established the Acceptable Daily Intake (ADI - is the amount of a specific substance in food that can be ingested orally over a lifetime without an appreciable health risk) for nitrate of $3,7 \mathrm{mg} \mathrm{kg}^{-1}$ body weight day ${ }^{-1}$. For nitrite, the ADI value is $0,07 \mathrm{mg} \mathrm{kg}^{-1}$ body weight day $^{-1}$. So, for a person with $60 \mathrm{~kg}$ body weight, the calculated value is $222 \mathrm{mg}$ nitrate ion day ${ }^{-1}$ and $4,2 \mathrm{mg}$ nitrite ion day ${ }^{-1}$ (EFSA, 2008).

Considering these aspects, the purpose of this paper is to quantify the amount of nitrates present in certain vegetables intensively consumed during spring, sources of food which if does not conform with the current recommendations of EFSA and EU, can become major factors of risk to public health. 


\section{Materials and Methods}

\section{Sample collection}

The study was conducted between March and May 2020. We considered 5 types of vegetable products intensively consumed in spring: lettuce (Lactuca sativa), curly lettuce (or Lollo - Lactuca sativa var. Crispa), Iceberg lettuce (Lactuca sativa lime Iceberg), spinach (Spinacia oleracea) and wild garlic (Allium ursinum).

The samples were collected from different commercial locations (outlets): hypermarkets, open markets, street trade and house gate trade.

By street trade we mean the sale of products obtained in household, in small quantities, in crowded and non-compliant residential spaces (between blocks of flats), illegal, but frequently encountered in cities.

By house gate trade we mean the sale of products obtained in household, in front of the gate of the house, illegal, but very widespread along congested roads. Sometimes large quantities of such products can be brokered and delivered on the open market.

Samples were collected as follows:

- salad and spinach samples were collected from 3 hypermarket stores, 8 pieces per sample from each product;

- samples of salad, spinach and wild garlic were collected from 4 open markets in Bucharest, 10 pieces of each product;

- samples of lettuce, curly lettuce, spinach and wild garlic were collected from the street trade in 4 districts of Bucharest, 10 pieces of each product;

- samples of lettuce, curly lettuce, spinach and wild garlic from house gate trade were collected from the roads from localities bordering Bucharest, located in $\mathrm{N}, \mathrm{S}, \mathrm{E}, \mathrm{V}, 10$ pieces of each product.

\section{Sample preparation}

Immediately after obtaining, the samples were washed with tap water to remove soil and impurities, then with deionized water and dried with paper. The samples were then shredded, packed in plastic bags, labeled and stored in a refrigerated box at $-24^{\circ} \mathrm{C}$ until analysis (as plant nitrates are sensitive to light and temperature).

\section{Nitrate determination}

Nitrate determination was performed with the HORIBA LAQUATWIN B-741 Nitrate meter, which rapidly measures nitrate ions using selective ion membranes. The volume of the undiluted sample was between 0.3-0.5 ml. The calibration of the device was done in two points, minimum and maximum, with the standard solutions delivered by the manufacturer. Prior to analysis, the samples were homogenized using a blender, and the analysis was performed on the undiluted sample.

\section{Statistical preparation}

Microsoft Office Excel was used to calculate all statistical parameters (mean, standard deviation, coefficient of variability, and mean error) and t-test (Student) for determination of difference significance between the mean value of different vegetable outlets origins.

\section{Results and Discussion}

Nitrate content in lettuce of different outlets origins varied between 1000 and $4900 \mathrm{mg} \mathrm{kg}^{-1}$, with average values presented in Table 1 and Figure 1. A large variability is found in the case of samples taken from hypermarkets and open markets, and in the case of streets trade and house gate trade, the value of the coefficient of variability reveals homogeneous samples, which denotes similar conditions of obtaining/keeping. We mention that the samples, in the case of the last two locations, were taken from several traders, and the products 
were fresh. In total, $39.58 \%$ of the total lettuce samples exceeded the maximum admissibility limit of the nitrate content for lettuce grown in the open air, i.e. $4000 \mathrm{mg} \mathrm{kg}^{-1}$.

Table 1. Statistical parameters for nitrate content in vegetables sample (lettuce and Lollo salad) of different outlets origins

\begin{tabular}{|c|c|c|c|c|c|c|}
\hline \multirow{2}{*}{ Source } & \multicolumn{3}{|c|}{ Lettuce } & \multicolumn{3}{|c|}{ Lollo salad } \\
\hline & $\bar{x} \pm s_{\bar{x}}$ & $s$ & $\mathrm{~V} \%$ & $\bar{x} \pm s_{\bar{x}}$ & $s$ & $\mathrm{~V} \%$ \\
\hline Hipermarket $_{1}$ & $1561.25 \pm 117.44$ & 332.36 & 21.29 & $1528.75 \pm 109.36$ & 309.49 & 20.24 \\
\hline Hipermarket $_{2}$ & $1562.50 \pm 121.95$ & 345.12 & 22.09 & $1580.00 \pm 133.72$ & 378.42 & 23.95 \\
\hline Hipermarket $_{3}$ & $1375.00 \pm 129.14$ & 365.47 & 26.58 & $1600.00 \pm 129.49$ & 366.45 & 22.90 \\
\hline Open Market $_{1}$ & $2080.00 \pm 126.41$ & 399.44 & 19.20 & $1810.00 \pm 122.52$ & 387.15 & 21.39 \\
\hline Open Market $_{2}$ & $2327.00 \pm 162.24$ & 512.68 & 22.03 & $2195.00 \pm 166.86$ & 527.28 & 24.02 \\
\hline Open Market $_{3}$ & $2070.00 \pm 143.71$ & 454.12 & 21.94 & $2147.00 \pm 169.92$ & 536.95 & 25.01 \\
\hline Open Market $_{4}$ & $1720.00 \pm 197.80$ & 625.03 & 36.34 & $2102.00 \pm 165.75$ & 523.76 & 24.92 \\
\hline Street Trade $_{1}$ & $4184.00 \pm 88.95$ & 281.08 & 6.72 & $4106.00 \pm 153.53$ & 485.16 & 11.82 \\
\hline Street Trade $_{2}$ & $4230.00 \pm 66.80$ & 211.08 & 4.99 & $4580.00 \pm 107.63$ & 340.10 & 7.43 \\
\hline${\text { Street } \text { Trade }_{3}}_{3}$ & $4500.00 \pm 85.70$ & 270.80 & 6.02 & $4625.00 \pm 146.02$ & 461.43 & 9.98 \\
\hline Street Trade $_{4}$ & $4310.00 \pm 119.76$ & 378.45 & 8.78 & $3915.00 \pm 120.28$ & 380.10 & 9.71 \\
\hline House Gate Trade $_{N}$ & $4314.00 \pm 87.85$ & 277.62 & 6.44 & $4445.00 \pm 99.64$ & 314.86 & 7.08 \\
\hline House Gate Trade s & $4528.00 \pm 83.28$ & 263.18 & 5.81 & $4793.00 \pm 105.98$ & 334.90 & 6.99 \\
\hline House Gate Trade ${ }_{\mathrm{E}}$ & $3540.00 \pm 162.87$ & 514.67 & 14.54 & $4333.00 \pm 146.01$ & 461.40 & 10.65 \\
\hline House Gate Trade $_{V}$ & $4320.00 \pm 105.2$ & 332.67 & 7.70 & $4840.00 \pm 144.02$ & 455.09 & 9.40 \\
\hline
\end{tabular}

$\bar{x}=$ mean (average); $s=$ standard deviation; $\mathrm{s}_{\overline{\mathrm{x}}}=$ mean error; $\mathrm{V} \%=$ variation coefficient

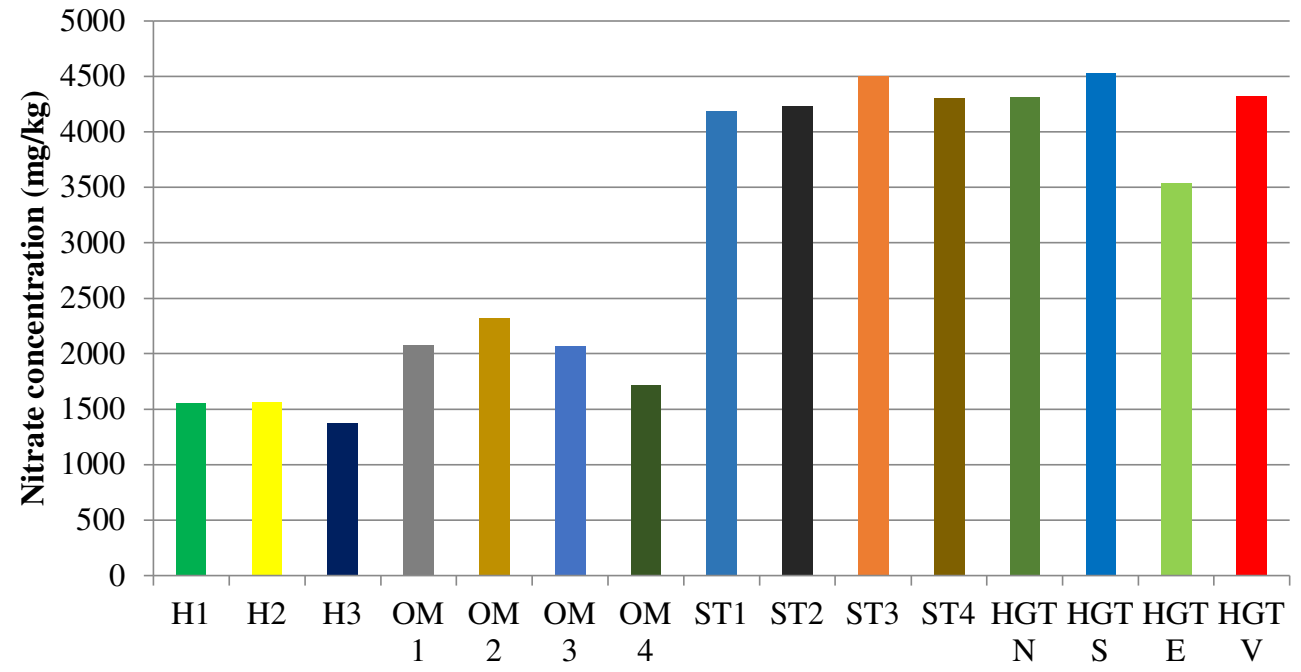

Figure 1. Average nitrate content in lettuce samples of different outlets origins $\left(\mathrm{mg} \mathrm{kg}^{-1}\right)$

$\mathrm{H}=$ hypermarket, $\mathrm{OM}=$ open market, $\mathrm{ST}=$ street trade, $\mathrm{HGT}=$ house gate trade

Regarding the nitrate content of the salad taken from hypermarkets, the samples showed an average content of $1499.58 \mathrm{mg} \mathrm{kg}^{-1}$, with variations between 1000 and $1945 \mathrm{mg} \mathrm{kg}^{-1}$, and the average nitrate content did not differ significantly between the three points. harvesting (Table 2). 
Table 2. Comparison between hypermarkets for nitrate content in lettuce samples ( $t$-test)

\begin{tabular}{|c|c|c|c|}
\hline Specification & $\mathrm{H}_{1}$ & $\mathrm{H}_{2}$ & $\mathrm{H} 3$ \\
\hline $\mathrm{H}_{1}$ & - & $0,0074^{\mathrm{NS}}$ & $1,0664^{\mathrm{NS}}$ \\
\hline $\mathrm{H}_{2}$ & & - & $1,0550^{\mathrm{NS}}$ \\
\hline
\end{tabular}

Lettuce samples collected from open markets revealed nitrate content of $2049.25 \mathrm{mg} \mathrm{kg}^{-1}$, with variations between 1100 and $2900 \mathrm{mg} \mathrm{kg}^{-1}$, and the high variability of this parameter certifies that, between producers, there are different conditions for obtaining. The value of the Student test shows that there are no significant differences between collection points, with one exception (Table 3), but the maximum admissibility limit is not exceeded.

Table 3. Comparison between open markets for nitrate content in lettuce samples ( $\mathrm{t}$-test)

\begin{tabular}{|c|c|c|c|c|}
\hline \multicolumn{1}{|c|}{ Specification } & $\mathrm{OM}_{1}$ & $\mathrm{OM}_{2}$ & $\mathrm{OM}_{3}$ & $\mathrm{OM}_{4}$ \\
\hline $\mathrm{OM}_{1}$ & - & $1,2018^{\mathrm{NS}}$ & $0,0523^{\mathrm{NS}}$ & $1,5347^{\mathrm{NS}}$ \\
\hline $\mathrm{OM}_{2}$ & & - & $1,1866^{\mathrm{NS}}$ & $2,3744^{*}$ \\
\hline $\mathrm{OM}_{3}$ & & & - & $1,4326^{\mathrm{NS}}$ \\
\hline
\end{tabular}

Lettuce samples collected from street trade revealed the highest nitrate content for lettuce ( $4306 \mathrm{mg} \mathrm{kg}$ ${ }^{1}$ ), with variations between 3800 and $4900 \mathrm{mg} \mathrm{kg}^{-1}$, under conditions of homogeneous samples. With two exceptions, there are no significant differences between the averages of the collection points (Table 4), in all cases exceeding the maximum admissibility limit.

Table 4. Comparison between street trade for nitrate content in lettuce samples ( $\mathrm{t}$-test)

\begin{tabular}{|l|c|c|c|c|}
\hline Specification & $\mathrm{ST}_{1}$ & $\mathrm{ST}_{2}$ & $\mathrm{ST}_{3}$ & $\mathrm{ST}_{4}$ \\
\hline $\mathrm{ST}_{1}$ & - & 0,4138 & $2,2563^{*}$ & $0,8452^{\mathrm{NS}}$ \\
\hline $\mathrm{ST}_{2}$ & & - & $2,4867^{*}$ & $0,5838^{\mathrm{NS}}$ \\
\hline $\mathrm{ST}_{3}$ & & & - & $1,2911^{\mathrm{NS}}$ \\
\hline
\end{tabular}

For house gate trade, the average nitrate content of the 4 collection points was $4175.5 \mathrm{mg} \mathrm{kg}^{-1}$, with limits between 2700 and $4900 \mathrm{mg} \mathrm{kg}^{-1}$. Similar to open markets, here too we encounter homogeneous production conditions. The collection points on the roads in the east of Bucharest stand out by values below the maximum admissibility limit, and the points in the south of Bucharest presented the highest nitrate content, above the limit, along with $\mathrm{N}$ and $\mathrm{V}$. Thus, the highly significant differences between the averages collection points will be generated by combinations containing point $\mathrm{E}$ (Table 5 ).

Table 5. Comparison between house gate markets for nitrate content in lettuce samples ( $\mathrm{t}$-test)

\begin{tabular}{|l|c|c|c|c|}
\hline \multicolumn{1}{|c|}{ Specification } & $\mathrm{HGT}_{\mathrm{N}}$ & $\mathrm{HGT}_{\mathrm{S}}$ & $\mathrm{HGT}_{\mathrm{E}}$ & $\mathrm{HGT}_{\mathrm{V}}$ \\
\hline $\mathrm{HGT}_{\mathrm{N}}$ & - & $1,7691^{\mathrm{NS}}$ & $4,1856^{* *}$ & $0,0438^{\mathrm{NS}}$ \\
\hline $\mathrm{HGT}_{\mathrm{S}}$ & & - & $5,4049^{* * *}$ & $1,5506^{\mathrm{NS}}$ \\
\hline $\mathrm{HGT}_{\mathrm{E}}$ & & & - & $4,0249^{* * *}$ \\
\hline
\end{tabular}

Interesting is the comparison between the average nitrate content of the salad between different outlets (Table 6).

Table 6. Comparison between different outlets for nitrate content in lettuce samples(t-test)

\begin{tabular}{|l|c|c|c|c|}
\hline \multicolumn{1}{|c|}{ Specification } & S & OM & ST & HGT \\
\hline S & - & $4,5171^{* * *}$ & $33,9033^{* * *}$ & $22,5404^{* * *}$ \\
\hline OM & & - & $23,2583^{* * *}$ & $18,1447^{* *}$ \\
\hline ST & & & - & $1,3764^{\mathrm{NS}}$ \\
\hline
\end{tabular}


The level of nitrates in salad exceeds the maximum allowable limit in the case of street market and house gate market, most likely due to cultivation, the amount of nutrients administered and historical pollution. It is a common practice among producers, almost impossible to control, although regulations exist, to manage large quantities of fertilizers, over necessary, often indiscriminately, out of the desire to go out with high production in late February, beginning of March. Unfortunately, all this has repercussions on the health of consumers, who find themselves in a situation of not being protected at all by the authorities. It can be seen from Table 6 that there are no significant differences between the two collection points, as a result both are uncertain sources. There are also differences between hypermarket and open market, but without exceeding the limits, the lowest value in the hypermarket being probably caused by more secure sources of supply.

Nitrate content in Lollo salad of different outlets origins varied between 1100 and $5500 \mathrm{mg} \mathrm{kg}^{-1}$, the average values per collection point being presented in Table 1 and figure 2 . A similar situation, as in the case of salad, is found in the case of Lollo salad, ie a heterogeneity of samples collected from hypermarkets and open markets, and a relative homogeneity in the case of street markets and hose gate markets. Of the total Lollo salad samples, $47.92 \%$ exceed the maximum limit of the maximum allowable nitrate content for lettuce grown in the open air, i.e. $4000 \mathrm{mg} \mathrm{kg}^{-1}$.

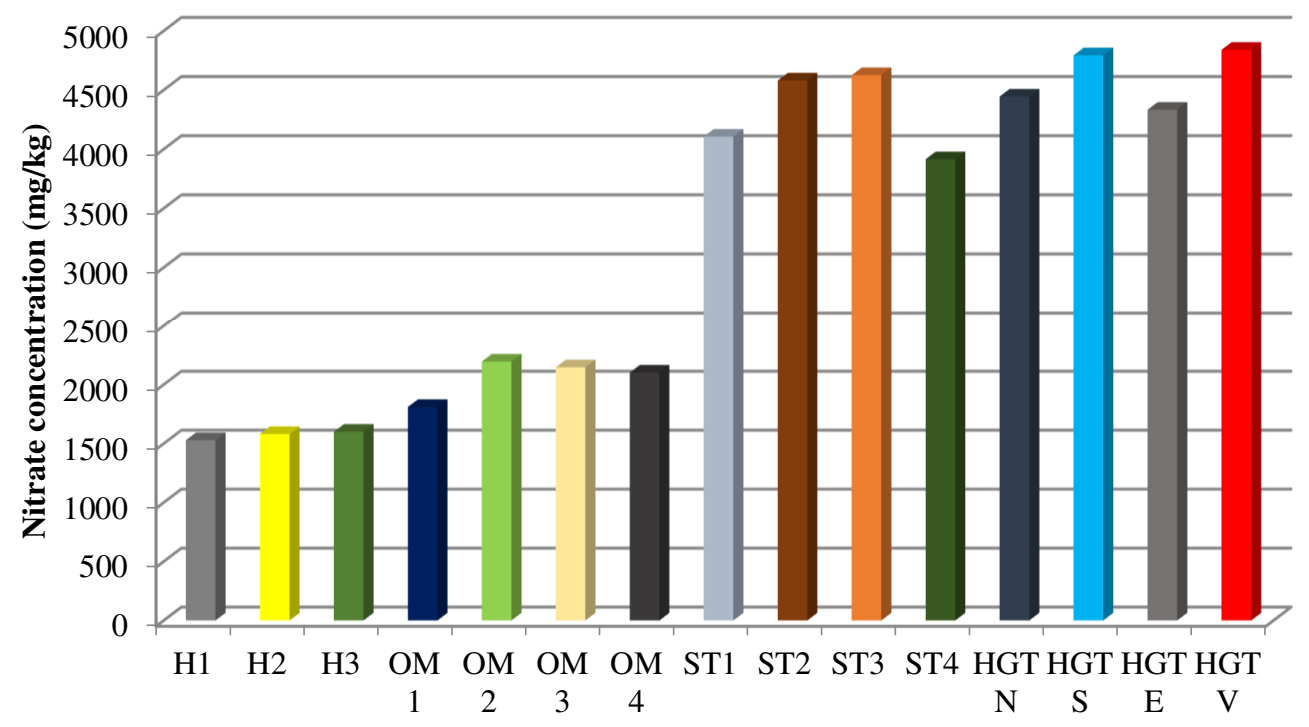

Figure 2. Average nitrate content in Lollo salad samples of different outlets origins $\left(\mathrm{mg} \mathrm{kg}^{-1}\right)$

$\mathrm{H}=$ hypermarket, $\mathrm{OM}=$ open market, $\mathrm{ST}=$ street trade, $\mathrm{HGT}=$ house gate trade

Samples of Lollo salad taken from hypermarkets showed the existence of an average nitrate content of $1569.38 \mathrm{mg} \mathrm{kg}^{-1}$, the limits varying between 1100 and $2050 \mathrm{mg} \mathrm{kg}^{-1}$. Between the averages of the three hypermarkets analyzed, the observed differences are statistically insignificant (Table 7).

Table 7. Comparison between hypermarkets for nitrate content in Lollo salad samples ( $\mathrm{t}$-test)

\begin{tabular}{|c|c|c|c|}
\hline Specification & $\mathrm{H}_{1}$ & $\mathrm{H}_{2}$ & $\mathrm{H} 3$ \\
\hline $\mathrm{H}_{1}$ & - & $0,2965^{\mathrm{NS}}$ & $0,4201^{\mathrm{NS}}$ \\
\hline $\mathrm{H}_{2}$ & & - & $0,1074^{\mathrm{NS}}$ \\
\hline
\end{tabular}

In open markets, the samples showed an average nitrate content of $2063.5 \mathrm{mgkg}^{-1}$, with variations between 1000 and $2950 \mathrm{mg} \mathrm{kg}^{-1}$. The samples were heterogeneous, which means that there are different 
conditions for obtaining between producers. There are no significant differences between the averages of samples collected from open markets (Table 8 ) and the maximum allowed limits have not been exceeded.

Table 8. Comparison between open markets for nitrate content in Lollo salad samples (t-test)

\begin{tabular}{|l|c|c|c|c|}
\hline Specification & $\mathrm{OM}_{1}$ & $\mathrm{OM}_{2}$ & $\mathrm{OM}_{3}$ & $\mathrm{OM}_{4}$ \\
\hline $\mathrm{OM}_{1}$ & - & $1,8611^{\mathrm{NS}}$ & $1,6099^{\mathrm{NS}}$ & $1,4177^{\mathrm{NS}}$ \\
\hline $\mathrm{OM}_{2}$ & & - & $0,2017^{\mathrm{NS}}$ & $0,3957^{\mathrm{NS}}$ \\
\hline $\mathrm{OM}_{3}$ & & & - & $0,1897^{\mathrm{NS}}$ \\
\hline
\end{tabular}

Regarding the Lollo salad samples collected from the street trade, the average nitrate content was 4306.5 $\mathrm{mg} \mathrm{kg}^{-1}$, with variations between 3200 and $5400 \mathrm{mg} \mathrm{kg}^{-1}$, given the existence of homogeneous samples. The differences observed between the collection points are statistical significance (Table 9), due to the higher average values recorded in ST2 and ST3. With the exception of ST4, the maximum admissibility limit is exceeded at the other points. This situation may be caused by chance, but regardless of the value recorded, does not certify such trade.

Table 9. Comparison between street trade for nitrate content in Lollo salad samples ( $\mathrm{t}$-test)

\begin{tabular}{|l|c|c|c|c|}
\hline Specification & $\mathrm{ST}_{1}$ & $\mathrm{ST}_{2}$ & $\mathrm{ST}_{3}$ & $\mathrm{ST}_{4}$ \\
\hline $\mathrm{ST}_{1}$ & - & $2,5298^{*}$ & $2,4512^{*}$ & $0,9800^{\mathrm{NS}}$ \\
\hline $\mathrm{ST}_{2}$ & & - & $0,2483^{\mathrm{NS}}$ & $4,1231^{\cdots *}$ \\
\hline $\mathrm{ST}_{3}$ & & & - & $3,7557^{\cdots *}$ \\
\hline
\end{tabular}

The samples collected from the associated house gate trade points had the highest average nitrate content for Lollo salad of $4602.75 \mathrm{mg} \mathrm{kg}^{-1}$, with variations between 3900 and $5400 \mathrm{mg} \mathrm{kg}^{-1}$. The value of the coefficient of variability reveals the existence of homogeneous samples, so similar production conditions. In all collection points the maximum admissibility limit is exceeded, the most affected areas being the south and west of Bucharest. They also generated statistically significant differences between the average nitrate content of Lollo salad (Table 10).

Table 10. Comparison between house gate markets for nitrate content in Lollo salad samples ( $\mathrm{t}$-test)

\begin{tabular}{|l|c|c|c|c|}
\hline \multicolumn{1}{|c|}{ Specification } & HGT $_{\mathrm{N}}$ & HGT $_{S}$ & HGT $_{\mathrm{E}}$ & HGT $_{\mathrm{V}}$ \\
\hline $\mathrm{HGT}_{\mathrm{N}}$ & - & $2,3941^{*}$ & $0,6340^{\mathrm{NS}}$ & $2,2571^{*}$ \\
\hline $\mathrm{HGT}_{S}$ & & - & $2,5514^{*}$ & $0,2630^{\mathrm{NS}}$ \\
\hline $\mathrm{HGT}_{\mathrm{E}}$ & & & - & $2,4739^{*}$ \\
\hline
\end{tabular}

The comparison between the average nitrate content of Lollo salad between different outlets is shown in Table 11.

Table 11. Comparison between different outlets for nitrate content in Lollo salad samples(t-test)

\begin{tabular}{|l|c|c|c|c|}
\hline \multicolumn{1}{|c|}{ Specification } & S & OM & ST & HGT \\
\hline S & - & $4,2689^{* * *}$ & $23,4138^{* * *}$ & $28,9378^{* * *}$ \\
\hline OM & & - & $19,8652^{* * *}$ & $24,0446^{* *}$ \\
\hline ST & & & - & $2,7847^{*}$ \\
\hline
\end{tabular}

There are significant differences between all collection points, but exceedances are also found in the case of street trade (with one exception, but close to the limit) and house gate trade. There are also differences between the hypermarket and the open market, but without exceeding the limits, the lower value in the hypermarket being probably caused by more secure sources of supply. 
The discussion is similar as in the case of lettuce and denotes the same serious situation, which can affect public health, the consumer being in a situation where he is completely vulnerable. Lollo salad is a product frequently sought after and consumed in the spring, and producers seek to enter the market as early as possible, sometimes using methods contrary to good practice.

Nitrate content in Iceberg salad of different outlets origins ranged from 1000 to $2800 \mathrm{mg} \mathrm{kg}^{-1}$, with mean values shown in Table 12 and Figure 3.

Table 12. Statistical parameters for nitrate content in vegetables sample (Iceberg salad, spinach, and wild garlic) of different outlets origins

\begin{tabular}{|c|c|c|c|c|c|c|c|c|c|}
\hline \multirow{2}{*}{ Source } & \multicolumn{3}{|c|}{ Iceberg salad } & \multicolumn{3}{|c|}{ Spinach } & \multicolumn{3}{|c|}{ Wild garlic } \\
\hline & $\bar{x} \pm s_{\bar{x}}$ & $s$ & V\% & $\bar{x} \pm s_{\bar{x}}$ & $s$ & $\mathrm{~V} \%$ & $\bar{x} \pm s_{\bar{x}}$ & $s$ & V\% \\
\hline Hipermarket $_{1}$ & $\begin{array}{c}1325.00 \pm \\
83.76\end{array}$ & 237.05 & 17.89 & $\begin{array}{c}1337.5 \\
\pm \\
92.85\end{array}$ & 262.77 & 19.65 & \multirow{3}{*}{\multicolumn{3}{|c|}{ No samples }} \\
\hline Hipermarket $2_{2}$ & $\begin{array}{c}1437.50 \\
\pm \\
130.12 \\
\end{array}$ & 368.23 & 25.62 & $\begin{array}{c}1393.75 \\
\pm \\
130.12\end{array}$ & 368.23 & 26.42 & & & \\
\hline Hipermarket $_{3}$ & $\begin{array}{c}1406.25 \\
\pm \\
66.78\end{array}$ & 188.98 & 13.44 & $\begin{array}{c}1387.5 \\
\pm \\
107.40\end{array}$ & 303.94 & 21.91 & & & \\
\hline Open Market $_{1}$ & $\begin{array}{c}2148.00 \\
\pm \\
100.92\end{array}$ & 318.91 & 14.85 & $\begin{array}{c}3493 \\
\pm \\
78.68\end{array}$ & 248.64 & 7.12 & $\begin{array}{c}660.00 \pm \\
33.19\end{array}$ & 104.88 & 15.89 \\
\hline Open Market $_{2}$ & $\begin{array}{c}2155.00 \\
\pm \\
133.52\end{array}$ & 421.93 & 19.58 & $\begin{array}{c}3515 \\
\pm \\
101.74\end{array}$ & 321.50 & 9.15 & $\begin{array}{c}546.00 \pm \\
44.48\end{array}$ & 140.57 & 25.75 \\
\hline Open Market 3 & $\begin{array}{c}2131.00 \\
\pm \\
30.66\end{array}$ & 96.89 & 4.55 & $\begin{array}{c}3357 \\
\pm \\
108.93\end{array}$ & 344.22 & 10.25 & $\begin{array}{c}465.00 \pm \\
82.07\end{array}$ & 259.33 & 55.77 \\
\hline Open Market 4 & $\begin{array}{c}2045.00 \\
\pm \\
99.08\end{array}$ & 313.09 & 15.31 & $\begin{array}{c}3512 \\
\pm \\
102.90\end{array}$ & 325.16 & 9.26 & $\begin{array}{c}633.00 \pm \\
70.81\end{array}$ & 223.76 & 35.35 \\
\hline Street Trade $_{1}$ & \multirow{4}{*}{\multicolumn{6}{|c|}{ No samples }} & $\begin{array}{c}515.00 \pm \\
69.19\end{array}$ & 218.64 & 42.45 \\
\hline Street Trade $_{2}$ & & & & & & & $\begin{array}{c}422.00 \pm \\
40.74\end{array}$ & 128.74 & 30.50 \\
\hline Street Trade $_{3}$ & & & & & & & $\begin{array}{c}363.00 \pm \\
32.45\end{array}$ & 102.53 & 28.25 \\
\hline Street Trade 4 & & & & & & & $\begin{array}{c}409.00 \pm \\
44.60\end{array}$ & 140.91 & 34.45 \\
\hline
\end{tabular}

A relatively high variability is found in the case of samples taken from hypermarkets, and in open markets, except for collection point No. 3 (where the sample is very homogeneous), the situation is similar. Iceberg salad samples were taken from open markets from several traders, and the products were fresh. No exceedances of the maximum admissibility limit of the nitrate content for lettuce grown in the open air were found, i.e. $4000 \mathrm{mg} \mathrm{kg}^{-1}$.

Regarding the Iceberg salad samples taken from hypermarkets, the average nitrate content was 1389.58 $\mathrm{mg} \mathrm{kg}^{-1}$, ranging from 1000 to $2000 \mathrm{mg} \mathrm{kg}^{-1}$. The calculated values of the Student test did not show significant differences between the averages of the three hypermarkets analyzed (Table 13). 


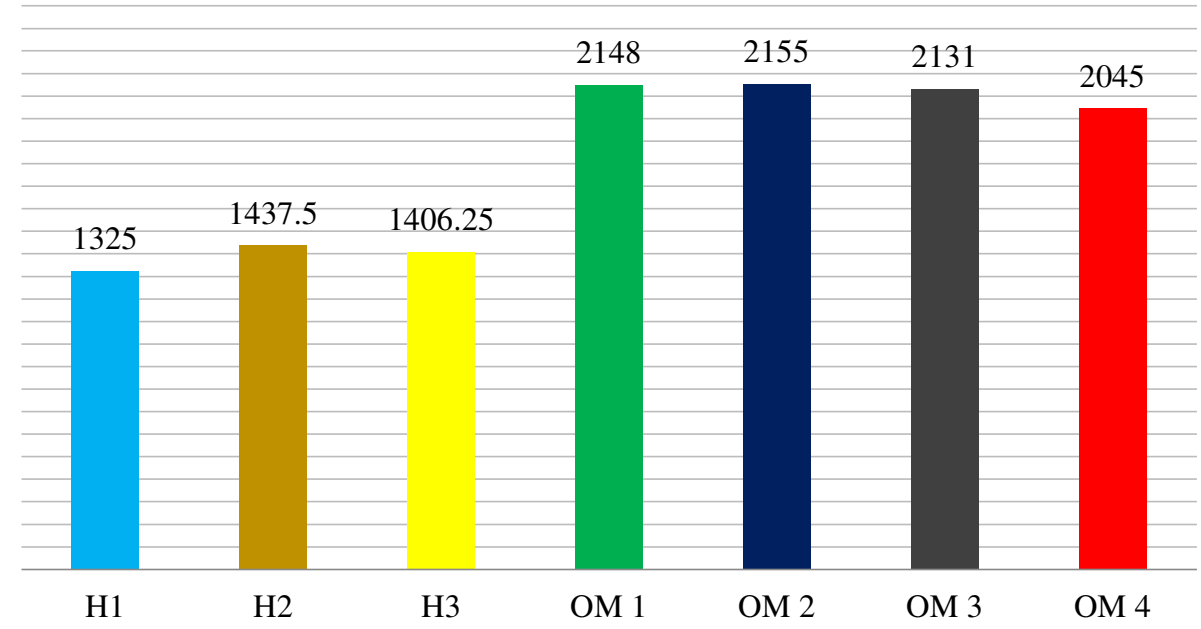

Figure 3. Average nitrate content in Iceberg salad samples of different outlets origins $\left(\mathrm{mg} \mathrm{kg}^{-1}\right)$ $\mathrm{H}=$ hypermarket, $\mathrm{OM}=$ open market

Table 13. Comparison between hypermarkets for nitrate content in Iceberg salad samples ( $\mathrm{t}$-test)

\begin{tabular}{|c|c|c|c|}
\hline Specification & $\mathrm{H}_{1}$ & $\mathrm{H}_{2}$ & $\mathrm{H} 3$ \\
\hline $\mathrm{H}_{1}$ & - & $0,7387^{\mathrm{NS}}$ & $0,7617^{\mathrm{NS}}$ \\
\hline $\mathrm{H}_{2}$ & & - & $0,2112^{\mathrm{NS}}$ \\
\hline
\end{tabular}

Iceberg salad samples collected from open markets revealed an average nitrate content of $2119.75 \mathrm{mg} \mathrm{kg}$ ${ }^{1}$, with variations between 1400 and $2800 \mathrm{mg} \mathrm{kg}^{-1}$, and the heterogeneity of the samples suggests that there are different conditions for obtaining between producers. The exception is OM3 where a small value of the coefficient of variability was found, the homogeneity in this case suggesting either similar conditions of obtaining or the supply of traders from the same producer (without being themselves producers). The value of the Student test shows that there are no significant differences between collection points (Table 14).

Table 14. Comparison between open markets for nitrate content in Iceberg salad samples ( $\mathrm{t}$-test)

\begin{tabular}{|c|c|c|c|c|}
\hline Specification & $\mathrm{OM}_{1}$ & $\mathrm{OM}_{2}$ & $\mathrm{OM}_{3}$ & $\mathrm{OM}_{4}$ \\
\hline $\mathrm{OM}_{1}$ & - & $0,0419^{\mathrm{NS}}$ & $0,1613^{\mathrm{NS}}$ & $0,7288^{\mathrm{NS}}$ \\
\hline $\mathrm{OM}_{2}$ & & - & $0,1753^{\mathrm{NS}}$ & $0,6621^{\mathrm{NS}}$ \\
\hline $\mathrm{OM}_{3}$ & & & - & $0,8298^{\mathrm{NS}}$ \\
\hline
\end{tabular}

Comparing the average nitrate content of Iceberg salad between the two outlets, there are highly significant differences $\left(t=9.7678^{* * *}\right)$, without exceeding the maximum allowable limit, the lower value in the hypermarket being probably caused of more secure sources of supply.

Nitrate content in spinach of different outlets origins varied between 1000 and $3970 \mathrm{mg} \mathrm{kg}^{-1}$, the average values per collection points being presented in Table 2 and Figure 4. From the analysis of the data presented in Table 2, a heterogeneity of the samples collected from hypermarkets and relative homogeneity in the case of open markets it is found. Of the total spinach samples, $26.56 \%$ exceed the maximum limit of the maximum allowable nitrate content for fresh spinach, i.e. $3500 \mathrm{mg} \mathrm{kg}^{-1}$. 


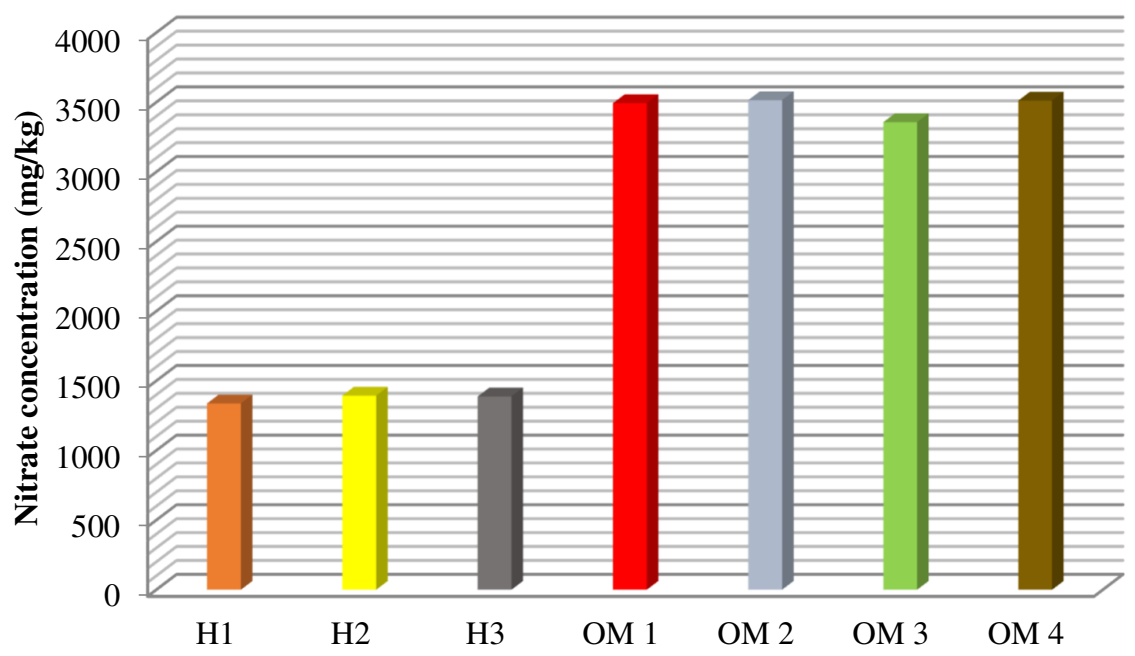

Figure 4. Average nitrate content in spinach samples of different outlets origins $\left(\mathrm{mg} \mathrm{kg}^{-1}\right)$ $\mathrm{H}=$ hypermarket, $\mathrm{OM}=$ open market

The spinach samples taken from hypermarkets showed an average nitrate content of $1372.92 \mathrm{mg} \mathrm{kg}^{-1}$, with variations between 1000 and $1800 \mathrm{mg} \mathrm{kg}^{-1}$. The heterogeneity of the samples is probably caused by the fact that the product comes from several producers. The maximum limit of admissibility is not exceeded, and the calculated values of the Student's test show differences without statistical significance between the collection points (Table 15).

Table 15. Comparison between hypermarkets for nitrate content in spinach samples ( $\mathrm{t}$-test)

\begin{tabular}{|c|c|c|c|}
\hline \multicolumn{1}{|c|}{ Specification } & $\mathrm{H}_{1}$ & $\mathrm{H}_{2}$ & $\mathrm{H} 3$ \\
\hline $\mathrm{H}_{1}$ & - & $0,3569^{\mathrm{NS}}$ & $0,3656^{\mathrm{NS}}$ \\
\hline $\mathrm{H}_{2}$ & & - & $0,0384^{\mathrm{NS}}$ \\
\hline
\end{tabular}

Regarding open markets, the average nitrate content of the spinach samples was $3469.25 \mathrm{mg} \mathrm{kg}^{-1}$, with variations between 2900 and $3970 \mathrm{mg} \mathrm{kg}^{-1}$, and the small variability of this parameter suggests that the homogeneity of the samples can be put on account of the existence of similar conditions of obtaining between producers, or the existence of a small number of producers from whom traders have been supplied. There are no significant differences between harvest points (Table 16), but high nitrate concentrations, two of which exceed the maximum admissibility limit raise public health problems and suggest, as in the case of other vegetables, non-compliant practices for high yields at the beginning of the season.

Table 16. Comparison between open markets for nitrate content in Iceberg salad samples ( $\mathrm{t}$-test)

\begin{tabular}{|c|c|c|c|c|}
\hline Specification & $\mathrm{OM}_{1}$ & $\mathrm{OM}_{2}$ & $\mathrm{OM}_{3}$ & $\mathrm{OM}_{4}$ \\
\hline $\mathrm{OM}_{1}$ & - & $0,1712^{\mathrm{NS}}$ & $1,0128^{\mathrm{NS}}$ & $0,1468^{\mathrm{NS}}$ \\
\hline $\mathrm{OM}_{2}$ & & - & $1,0608^{\mathrm{NS}}$ & $0,0207^{\mathrm{NS}}$ \\
\hline $\mathrm{OM}_{3}$ & & & - & $1,0351^{\mathrm{NS}}$ \\
\hline
\end{tabular}

There are differences between the two outlets with high statistical significance $\left(t=26.8945^{* *}\right)$, the lower value in the hypermarket being probably caused by more secure sources of supply.

Wild garlic (Romanian: "leurdă") is a plant that grows in wetlands, for Bucharest the main sources of supply are the forests around the city, or river meadows that cross neighboring towns. It can be cultivated, but 
less often, due to difficulties, but its origin in Bucharest is usually from the wild flora. It is a plant much appreciated during this period, due to its taste qualities and phyto-therapeutic properties.

Nitrate content in wild garlic of different outlets origins varied between 100 and $900 \mathrm{mg} \mathrm{kg}^{-1}$, the average values per collection point being presented in Table 2 and Figure 5. The high heterogeneity of the samples from both collection points is determined, most likely, by the wild garlic harvesting area (in the river meadow, the nitrate content is expected to be higher compared to the forest). There can be no question of the existence of exceedances of the maximum admissibility limit, on the one hand because there is no standard, and on the other hand because it does not come from culture.

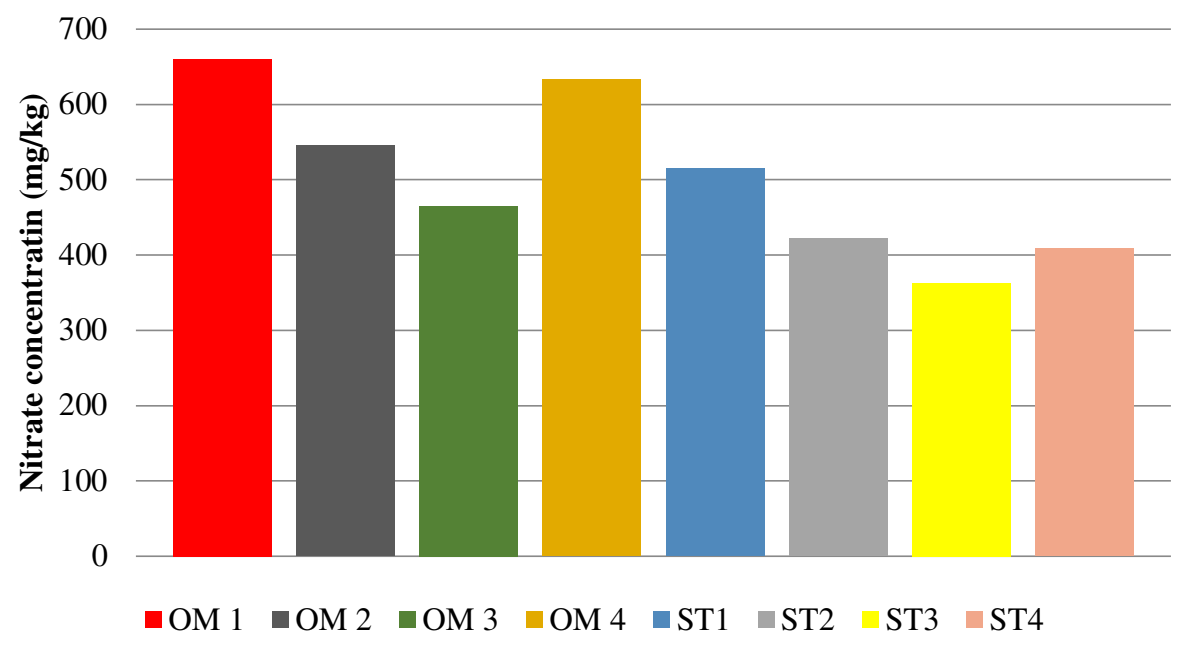

Figure 5. Average nitrate content in wild garlic samples of different outlets origins $\left(\mathrm{mg} \mathrm{kg}^{-1}\right)$

$\mathrm{OM}=$ open market, $\mathrm{ST}=$ street trade

Wild garlic samples collected from open markets revealed an average nitrate content of $576 \mathrm{mg} \mathrm{kg}^{-1}$, with variations between 100 and $900 \mathrm{mg} \mathrm{kg}^{-1}$. The value of the Student's test shows that there are no significant differences between collection points, with two exceptions generated by OM2 and OM3 (Table 17).

Table 17. Comparison between open markets for nitrate content in wild garlic samples ( $t$-test)

\begin{tabular}{|l|c|c|c|c|}
\hline \multicolumn{1}{|c|}{ Specification } & $\mathrm{OM}_{1}$ & $\mathrm{OM}_{2}$ & $\mathrm{OM}_{3}$ & $\mathrm{OM}_{4}$ \\
\hline $\mathrm{OM}_{1}$ & - & $2,0555^{*}$ & $2,2044^{*}$ & $0,3455^{\mathrm{NS}}$ \\
\hline $\mathrm{OM}_{2}$ & & - & $0,8684^{\mathrm{NS}}$ & $1,0411^{\mathrm{NS}}$ \\
\hline $\mathrm{OM}_{3}$ & & & - & $1,5511^{\mathrm{NS}}$ \\
\hline
\end{tabular}

Regarding the wild garlic samples collected from the street trade, the average nitrate content was 427.25 $\mathrm{mg} \mathrm{kg}$, with variations between 150 and $900 \mathrm{mg} \mathrm{kg}^{-1}$, given the existence of heterogeneous samples. The differences observed between collection points are not statistically significant (Table 18).

Table 18. Comparison between street trade for nitrate content in wild garlic samples (t-test)

\begin{tabular}{|l|c|c|c|c|}
\hline Specification & $\mathrm{ST}_{1}$ & $\mathrm{ST}_{2}$ & $\mathrm{ST}_{3}$ & $\mathrm{ST}_{4}$ \\
\hline $\mathrm{ST}_{1}$ & - & $1,1591^{\mathrm{NS}}$ & $1,9904^{\mathrm{NS}}$ & $1,2887^{\mathrm{NS}}$ \\
\hline $\mathrm{ST}_{2}$ & & - & $1,1337^{\mathrm{NS}}$ & $0,2154^{\mathrm{NS}}$ \\
\hline $\mathrm{ST}_{3}$ & & & - & $0,8384^{\mathrm{NS}}$ \\
\hline
\end{tabular}


Between the two outlets it is found the existence of differences with high statistical significance $(t=$ $\left.3.6845^{\circ *}\right)$, caused by the high heterogeneity of the samples.

The results obtained by us regarding the content of nitrates from different vegetable sources that enter in the human diet are part of a whole mosaic of values, the literature being extremely heterogeneous, given the experimental conditions, collecting points, influencing factors, etc. Temme (2011) states that half of the daily nitrate intake of Belgians is of vegetable origin. Similar results are obtained by Petersen and Stoltze (1999) who, based on samples collected from different shopping centers, find large amounts of nitrates in spinach $(2508 \mathrm{mg}$ $\left.\mathrm{kg}^{-1}\right)$, in lettuce $\left(2167 \mathrm{mg} \mathrm{kg}^{-1}\right)$. Nunez de Gonzales (2015), in a study conducted in the USA, reports an average nitrate content of $1496 \mathrm{mg} \mathrm{kg}^{-1}$ for celery, $851 \mathrm{mg} \mathrm{kg}^{-1}$ for lettuce and $2797 \mathrm{mg} \mathrm{kg}^{-1}$ for spinach. Zhong et al. (2002) find in spinach an average nitrate content of $4259 \mathrm{mg} \mathrm{kg}^{-1}$. Iammarino et al. (2014) also find high values of nitrate content, above the legal limit, in lettuce and spinach.

It is generally recognized that mineral fertilizers are applied in excess in order to maximize production (Stewart et al., 2005). In particular, excess nitrogen from fertilizers leads to increased accumulation of nitrates in the leaves, which could have a negative impact on human health (Islam et al., 2012). However, there is research that has shown that a high content of nitrates can also occur in the edible wild flora. Thus, the research conducted by Cakilcioglu and Khatun (2011) showed in some edible plants a high content of nitrates, even if the samples were taken from the natural flora. The authors reported a nitrate content of $6560.95 \mathrm{mg} \mathrm{kg}^{-1}$ in Portulaca oleracea and $3850.73 \mathrm{mg} \mathrm{kg}^{-1}$ in Urtica dioica.

In plant species of wild flora, a high nitrate content can occur for two reasons: either due to the washing of nutrients from neighboring or upstream agricultural lands, or due to the high nitrate load in surface waters.

As previously mentioned, EFSA set the ADI value for nitrates, setting a quantity of $222 \mathrm{mg}$ nitrate ion day $^{-1}$ for a $60 \mathrm{~kg}$ person.

According to European regulations, for a healthy person, the recommendation is a consumption of at least $400 \mathrm{~g}$ of vegetables day ${ }^{-1}$ (https://ec.europa.eu/jrc/en/health-knowledge-gateway/promotionprevention/nutrition/fruit-vegetables).

Analyzing the consumption of $100 \mathrm{~g}^{\text {day }}{ }^{-1}$ of vegetables from different outlets and the variation compared to ADI (Table 19), an interesting situation is highlighted.

Table 19. Nitrate intake $(\mathrm{mg})$ by consuming $100 \mathrm{~g} \mathrm{day}^{-1}$ of vegetables of different origins and deviation from ADI

\begin{tabular}{|l|c|c|c|c|c|c|c|c|c|c|}
\hline $\begin{array}{l}\text { Specifi- } \\
\text { cation }\end{array}$ & Lettuce & $\begin{array}{c} \pm \text { ADI } \\
(\%)\end{array}$ & $\begin{array}{c}\text { Lollo } \\
\text { salad }\end{array}$ & $\begin{array}{c} \pm \text { ADI } \\
(\%)\end{array}$ & $\begin{array}{c}\text { Iceberg } \\
\text { salad }\end{array}$ & $\begin{array}{c} \pm \text { ADI } \\
(\%)\end{array}$ & Spinach & $\begin{array}{c} \pm \text { ADI } \\
(\%)\end{array}$ & $\begin{array}{c}\text { Wild } \\
\text { garlic }\end{array}$ & $\begin{array}{c} \pm \text { ADI } \\
(\%)\end{array}$ \\
\hline H & 150 & $-32,43$ & 157 & $-29,28$ & 139 & $-37,39$ & 137 & $-38,29$ & - & \\
\hline OM & 205 & $-7,66$ & 206 & $-7,21$ & 212 & $-4,50$ & 347 & 56,31 & 58 & $-73,87$ \\
\hline ST & 431 & 94,14 & 431 & 94,14 & - & - & - & & 43 & $-80,63$ \\
\hline HGT & 418 & 88,29 & 460 & 107,21 & - & - & - & & - & \\
\hline
\end{tabular}

Consumption of 100 grams of vegetables with the lowest nitrate content found by us (wild garlic) would mean an intake of $43 \mathrm{mg}$, which for a person of $60 \mathrm{~kg}$, according to EFSA, would mean about $21 \%$ of the amount recommended daily. At the other extreme, according to the results obtained by us, the consumption of 100 grams of Lollo salad purchased from HGT would cause an exceedance of $107.21 \%$ of the maximum recommended limit.

The values we find are worrying for certain sampling points. The values significantly exceed the maximum admissibility limit exactly where the control of the authorities can be exercised the least or at all. Thus, from this point of view, trade with vegetables for consumption from ST or HGT, is a danger to public health. As we have already stated, out of the desire to enter the market as early as possible with vegetable products in high demand for consumption in spring, some producers or growers without a certificate overchemicalize crops, or apply fertilizers indiscriminately, without a soil analysis, without a fertilization plan. 
At present, especially in large urban agglomerations, there is a favorable current for the purchase of these products from ST or HGT, in the idea that such products would be "healthier", being produced by "peasants", on the one hand, and on the other from the desire to help people in rural areas who can supplement their income by practicing such a trade. We point out that this practice is not always good for health. Every consumer should keep in mind that vegetables are not the only source of nitrates, as humans take these ions from other sources, so there is a possibility of frequently exceeding the maximum allowable intake. At the same time, for the sake of fairness, the situation cannot be generalized and, from this point of view, the control of the state authorities is essential.

\section{Conclusions}

Leafy vegetables are the plants that enter the human diet with the highest nitrate content and the highest accumulation rate. Nitrate intake above the maximum allowable limit can have a negative impact on human health, given that vegetables are not the only source. There are a number of factors that influence the amount of nitrates in plants but, most likely, the application of chemical fertilizers (quantitative) is the major factor. There is a high variability of nitrate content in the studied biological entities, both between collection points and within the same point. The results obtained by us in this paper suggest that ST and HGT are commercial points that may constitute a danger to public health. The lack of control and coercive measures encourages such trade, on the one hand, and on the other hand allows the application of fertilizers without discernment, from the desire to obtain large yields in early spring. The danger to human health is highlighted by exceeding the ADI value even by $107.21 \%$ in the case of Lollo salad purchased from HGT. Consumption of vegetables from safe, regulated and controlled sources, without discouraging any trade, would significantly reduce the intake of nitrates in adults and thus contribute to reducing the risk of pathologies associated with nitrate consumption in the human population.

\section{Authors' Contributions}

Conceptualization: DCP and RAP; Data curation: RAP and CRV; Formal analysis: ENP, MT, and MPM; Investigation: DCP, RAP, LV, and CRV; Methodology: DCP and ENP; Supervision: MPM and LV; Writing - original draft: DCP and RAP; Writing - review and editing: DCP, RAP, LV, and ENP.

All authors read and approved the final manuscript.

\section{Acknowledgements}

This research received no specific grant from any funding agency in the public, commercial, or not-forprofit sectors.

\section{Conflict of Interests}

The authors declare that there are no conflicts of interest related to this article. 
Popa DC et al. (2021). Not Bot Horti Agrobo 49(2):12340

\section{References}

Abu-Rayyan A, Kharawish BH, Al-Ismail K (2004). Nitrate content in lettuce (Lactuca sativa L.) heads in relation to plant spacing, nitrogen form and irrigation level. Journal of the Science of Food and Agriculture 84(9):931-936. https://doi.org/10.1002/jsfa.1733

Assimakopoulou A (2006). Effect of iron supply and nitrogen form on growth, nutritional status and ferric reducing activity of spinach in nutrient solution culture. Scientia Horticulturae 110(1):21-29. https://doi.org/10.1016/j.scienta.2006.06.010

Cakilcioglu U, Khatun S (2011). Nitrate, moisture and ash contents of edible wild plants. Journal of Cell \& Plant Sciences 2(1):1-5.https://www.researchgate.net

Chen S, Shen X, Cheng S, Li P, Du J, Chang Y, Meng H (2013). Evaluation of garlic cultivars for polyphenolic content and antioxidant properties. PLoS One 8(11):e79730. https://doi.org/10.1371/journal.pone.0079730

Emongor V, Pule-Meulengerg F, Phole O (2004). Effect of promalin on growth and development of kale (Brassica oleracea L. var. acephala). Journal of Agronomy 3(3):208-214. https://doi.org/10.3923/ja.2004.208.214

European Food Safety Authority (2008). Nitrate in vegetables: scientific opinion of the panel on contaminants in the food chain. EFSA Journal 689:4-75. https://www.efsa.europa.eu/en/efsajournal/pub/689

Fageria VD (2001). Nutrient interactions in crop plants. Journal of Plant Nutrition 24(8):1269-1290. https://doi.org/10.1081/PLN-100106981

Findenegg GR (1987). A comparative study of ammonium toxicity at different constant $\mathrm{pH}$ of the nutrient solution. Plant and Soil 103(2):239-243. https://link.springer.com/article/10.1007/BF02370395

Gaikwad PS, Shete RV, Otari KV (2010). Spinacia oleracea Linn: a pharmacognostic and pharmacological overview. International Journal of Research in Ayurveda and Pharmacy 1(1):78-84. https://fdocuments.in

Gangolli SD, van den Brandt PA, Feron VJ, Janzowsky C, Koeman JH, Speijers GJ (1994). Nitrate, nitrite and N-nitroso compounds. Environmental Toxicology Pharmacology 292(1):5-32. https://doi.org/10.1016/09266917(94)90022-1.23

Gatseva Penka, Vladeva Stefka, Argirova Mariana (2007). Evaluation of endemic goiter prevalence in Bulgarian schoolchildren. Biological Trace Element 116(3):273-278. https://link.springer.com/content/pdf/10.1007/BF02698011.pdf

Gorenjak AH, Cencič A (2013). Nitrate in vegetables and their impact on human health. A review. Acta Alimentaria 42(2):158-172. http://dx.doi.org/10.1556/AAlim.42.2013.2.4

Guo S, Brtick H, Sattelmacher B (2013). Effect of $\mathrm{NH}_{4}^{+} / \mathrm{NO}_{3}$ ratios on the growth and bolting stem glucosinolate content of Chinese kale (Brassica alboglabra L.H. Bailey). Australian Journal of Crop Science 7(5):618-624. https://search.informit.org/doi/abs/10.3316/INFORMIT.364612537595333

Hudak PF (2000). Regional trends in nitrate content of Texas groundwater. Journal of Hydrology 228:37-47. https://doi.org/10.1016/S0022-1694(99)00206-1

Iacob O, Tudor A, Neamțu A, Cristea A (2012). Water well. Guideline for family and hygienic doctors. Public Health Department, Population, pp 10-12. https://cnmrmc.insp.gov.ro/images/ghiduri/Ghid-Apa-De-Fantana.pdf.

Iammarino M, Di Taranto A, Cristino M (2014). Monitoring of nitrites and nitrates levels in leafy vegetables (spinach and lettuce): a contribution to risk assessment. Journal of the Science of Food and Agriculture 94:773-778. https://doi.org/10.1002/jsfa.6439

Iarc Working Group on the Evaluation of Carcinogenic Risks to Humans (2010). IARC monographs on the evaluation of carcinogenic risks to humans. Ingested nitrate and nitrite, and cyanobacterial peptide tox-ins. IARC Monography Evaluation Carcinogenic Risks Human. 94:v-vii. 7-212. https://monographs.iarc.who.int/wpcontent/uploads/2018/06/mono94.pdf

Islam MS, Ahmed A, Mahmud S, Tusher TR, Khanom S (2012). Effects of organic fertilizer on the growth and yield of lettuce (Lactuca sativa L.) used as vegetables. International Journal of Agricultural Science and Research 2:116128. https://www.academia.edu

Kopsell DE, Kopsell DA, Lefsrud MG, Curran-Celentano J (2004). Variability in elemental accumulations among Leafy Brassica oleracea cultivars and selections. Journal of Plant Nutrition 27(10):1813-1826. https://doi.org/10.1081/PLN-200026431

Kotsiras A, Olympios CM, Drosopoulos J, Passam HC (2002). Effects of nitrogen form and concentration on the distribution of ions within cucumber fruits. Scientia Horticulturae 95:175-183. https://doi.org/10.1016/S0304-4238(02)00042-0 
Lahl U, Zeschmar B, Gabel B, Kozincki R, Podbielcki A, Stachel B, Struss S (1983). Ground water pollution by nitrate. International Symposium on ground water in water resources planning, vol II, Koblenz. http://hydrologie.org/redbooks/a142/142098.pdf

Marschner H (2011). Mineral nutrition of higher plants. $3^{\text {th }}$ Editions. London (UK): Academic Press.

McKnight GM, Smith LM, Drummond RS, Duncan CW, Golden M, Benjamin N (1997). Chemical synthesis of nitric oxide in the stomach from dietary nitrate in humans. Gut 40:211-214. https://doi.org/10.1136/gut.40.2.211

Mengel K, Planker R, Hoffman B (1994). Relationship between leaf apoplast $\mathrm{pH}$ and Fe chlorosis of sunflowers (Helianthus annuus L.). Journal of Plant Nutrition 17(6):1053-1064. https://doi.org/10.1080/01904169409364787

Mensinga TT, Speijers GJ, Meulenbelt J. (2003). Health implications of exposure to environmental nitrogenous compounds. Toxicology Reviews 22(1):40-50. https://doi.org/10.2165/00139709-200322010-00005

Metha D and Belemkar S (2014). Pharmacological activity of Spinacia oleracea Linn. A complete overview. Asian Journal of Pharmaceutical Research and 2(1):83-93. https://www.ajprd.com/index.php/journal/article/view/264/234

Morales-Suarez-Varela MM, Llopis-Gonzalez A, Tejerizo-Perez ML (1995). Impact of nitrates in drinking water on cancer mortality in Valencia, Spain. European Journal of Epidemiology 11(1):15-21. https://doi.org/10.1007/BF01719941

Nuñez de González MT, Osburn WN, Hardin MD, Longnecker M, Garg HK, Bryan NS, Keeton JT (2015). A survey of nitrate and nitrite concentrations in conventional and organic-labeled raw vegetables at retail. Journal of Food Science 80(5):C942-949. https://doi.org/10.1111/1750-3841.12858

Oszmianski J, Kolniak-Ostek J, Wojdylo A (2013). Characterization and content of flavonol derivatives of Allium ursinum L. plant. Journal of Agricultural and Food Chemistry 61:176-184. https://doi.org/10.1021/jf304268e

Palli D, Saieva C, Coppi C, Del Giudice G, Magagnotti C, Nesi G, ... Airoldi L (2001) O6-alkylguanines, dietary Nnitroso compounds, and their precursors in gastric cancer. Nutrition and Cancer 39(1):42-49. https://doi.org/10.1207/S15327914nc391_6

Pennington JAT (1998). Dietary exposure models for nitrates and nitrites. Food Control 9(6):385-95. https://doi.org/10.1016/s0956-7135(98)00019-x.24

Petersen A, Stoltze S (1999). Nitrate and nitrite in vegetables on the Danish market: content and intake. Food Additive and Contaminants 16:291-299. https://doi.org/10.1080/026520399283957

Rideout JW, Chaillou S, Rape CD, Morot-Gaudry JF (1994). Ammonium and nitrate uptake by soybean during recovery from nitrogen deprivation. Journal of Experimental Botany 45(1):23-33. https://doi.org/10.1093/jxb/45.1.23

Santamaria P, Elia A (1997). Producing nitrate free endive heads: Effect of nitrogen form on growth, yield and ion composition of endive. Journal of the American Society for Horticultural Science 122(1):140-145. https://doi.org/10.21273/JASHS.122.1.140

Santamaria P, (2006). Nitrate in vegetables: toxicity, content, intake and EC regulation. Journal of the Science of Food and Agriculture 86:10-17. https://doi.org/10.1002/jsfa.2351

Simonne EH, Smittle DA, Mills HA (1993). Turnip growth, leaf yield, and leaf nutrient composition responses to nitrogen forms. Journal of Plant Nutrition 16(12):2341-2351. https://doi.org/10.1080/01904169309364692

Skipton, S, DeLynn H (1998). Drinking water: nitrate and methemoglobinemia ("Blue Baby" Syndrome). Historical Materials from University of Nebraska-Lincoln 1435. https://digitalcommons.unl.edu/extensionhist/1435

Smiciklas KD, Below FE (1992). Role of nitrogen form in determining yield of field-grown maize. Crop Science 32(5):1220-1225. https://doi.org/10.2135/cropsci1992.0011183X003200050032x

Stewart WM, Dibb DW, Johnston AE, Smyth TJ (2005). The contribution of commercial fertilizer nutrients to food production. Agronomy Journal 97:1-6. https://doi.org/10.2134/agronj2005.0001

Still DW (2007). Lettuce. In: Kole C (Ed.). Genome Mapping and Molecular Breeding in Plants. Vol 5, Vegetables. Springer-Verlag Berlin Heidelberg pp 71-84. https://doi.org/10.1007/978-3-540-34536-7_2

Temme EH, van Devijvere S, Vinkx C, Huybrechts I, Goeyens L, van Oyen H (2011). Average daily nitrate and nitrite intake in the Belgian population older than 15 years. Food Additive Contaminants Part A 28:1193-204. https://doi.org/10.1080/19440049.2011.584072

Trifunschi S, Munteanu M, Pogurschi E, Gligor R (2017). Characterization of polyphenolic compounds in Viscum album L. and Allium sativum L. extracts. Revista de Chimie 68(7):1677-1680. https://doi.org/10.37358/RC.17.7.5741 
van Duijvenboden W, Matthijsen AJCM (1989). Integrated criteria document nitrate. Bilthoven, Rijksintituutvoor de Volksgezondhei den Milieuhygiëne (National Institute of Public Health and Environmental Protection) (RIVM Report No. 758473012) 64-74. https://www.rivm.nl/bibliotheek/rapporten/758473012.pdf

Verma S (2018). A study on medicinal herb Spinacia oleraceae Linn: Amaranthaceae. Journal of Drug Delivery and Therapeutics 8(4):59-61. https://doi.org/10.22270/jddt.v8i4.1767

Wang Z, Li S (2004). Effects of nitrogen and phosphorus fertilization on plant growth and nitrate accumulation in vegetables. Journal of Plant Nutrition 27(3):539-556. https://doi.org/10.1081/PLN-120028877

Zhang FC, Kang SZ, Li FS, Zhang JH (2007). Growth and major nutrient concentrations in Brassica campestris supplied with different $\mathrm{NH}_{4}+/ \mathrm{NO}_{3}$ ratios. Journal of Integrative Plant Biology 49(4):455-462. https://doi.org/10.1111/j.1744-7909.2007.00373.x

Zhong W, Hu C, Wang M (2010). Nitrate and nitrite in vegetables from north China: content and intake. Food Additive and Contaminants 19(12):1125-1129. https://doi.org/10.1080/0265203021000014806

Commission Regulation EU (2011). Commission Regulation no.1258/2011. https://eur-lex.europa.eu

OPEN ACCESS

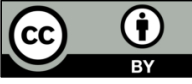

The journal offers free, immediate, and unrestricted access to peer-reviewed research and scholarly work. Users are allowed to read, download, copy, distribute, print, search, or link to the full texts of the articles, or use them for any other lawful purpose, without asking prior permission from the publisher or the author.

License - Articles published in Notulae Botanicae Horti Agrobotanici Cluj-Napoca are Open-Access, distributed under the terms and conditions of the Creative Commons Attribution (CC BY 4.0) License.

(c) Articles by the authors; UASVM, Cluj-Napoca, Romania. The journal allows the author(s) to hold the copyright/to retain publishing rights without restriction. 